\title{
Postbiotic Gamma-Aminobutyric Acid and Camel Milk Intervention as Innovative Trends Against Hyperglycemia and Hyperlipidemia in Streptozotocin-induced C57BL/6J Diabetic Mice
}

\section{Amro Abdelazez ( $\sim$ amorbiotic@yahoo.com )}

Northeast Agricultural University https://orcid.org/0000-0001-6895-6277

Garsa Alshehry

Taif University College of Science

Eman Algarni

Taif University College of Science

Huda Al-jumayi

Taif University College of Science

HEBA MAHMOUD Abdelmotaal

Agriculture research center

\section{Xiang-Chen Meng}

Northeast Agricultural University

\section{Research Article}

Keywords: postbiotic, Gamma-aminobutyric acid, Lactobacillus brevis, diabetes type 1, camel milk, C57BL/6 mice

Posted Date: February 10th, 2022

DOI: https://doi.org/10.21203/rs.3.rs-1295254/v1

License: (c) (i) This work is licensed under a Creative Commons Attribution 4.0 International License. Read Full License 


\section{Abstract}

Diabetes is a serious disease that threatens human health worldwide. The study hypothesis is to investigate the novel trends that may aid in the prevention of diabetic complications. Camel milk was presented as a functional food, and Lactobacillus brevis KLDS $_{1.0727}$ and $\mathrm{KLDS}_{1.0373}$ ) strains were shown to synthesize postbiotic GABA as a potential food additive, which can therapeutically intervene against hyperglycemia and hyperlipidemia in streptozotocin-induced $\mathrm{C}_{57} \mathrm{BL} / 6$ mice. During a four-week timeframe, body weight and postprandial blood glucose levels were monitored. Post euthanasia, blood plasma was obtained to investigate hyperlipidemia, insulin concentrations, liver, and renal functions. The liver, pancreas, kidney, and spleen underwent histological examinations. The results demonstrated that $\mathrm{KLDS}_{1.0727}$ and $\mathrm{KLDS}_{1.0373}\left(\mathrm{LAC}_{\mathrm{S1}}, \mathrm{LAC}_{\mathrm{S} 2}\right)$, and camel milk treatments all had a significant influence on hypoglycemic activity, as evidenced by reduced postprandial blood glucose levels. $\mathrm{LAC}_{\mathrm{S} 1}, \mathrm{LAC}_{\mathrm{S} 2}$, and camel milk therapy significantly reduced blood hypolipidemic, ALT, and AST levels. Camel milk is recommended for its therapeutic benefits in the treatment of hyperglycemia and hyperlipidemia in the management of diabetes and comorbidities as well as, GABA which is considered a potential food additive.

\section{Introduction}

Diabetes is rapidly becoming a global epidemic. It's also classified as a lifestyle disease and a critical metabolic disorder that developed with postprandial hyperglycemia which is mostly caused by insulin resistance (Patil et al. 2015). Organ failure, hypertension, hyperlipidemia, cardiovascular disease, as well as pancreatic oxidative stress, all lead to $\beta$-cell destruction and reduced insulin sensitivity. Therefore, all of these inevitable factors may lead to mortality for diabetic patients (Di Martino et al. 2021).

Currently, scientists are looking for innovative ways to manage diabetes complications, particularly from natural sources such as functional foods. Non-pharmacological daily activities (e.g., diet, exercise, and weight loss) and pharmaceutical alternatives (e.g., insulin stimulators, insulin inhibitors, and glucosidase inhibitors) are two strategies for lowering diabetes prevalence. However, Complementary and alternative medications may have some negative side effects (Verhaegen and Van Gaal 2021).

The interaction between the microbiota and human health disorders has become increasingly emerged (Suzzi and Corsetti 2020). The gut-brain axis provides new insight into the interactions between the intestine and the brain across different pathways and molecules, such as the intestinal nervous system, the vagus nerve, microbial metabolites, and the immune system via gut microbiota functions that regulate the central nervous system (Jones et al. 2020).

Before using the word "Postbiotic" or using it as a food component, the US Food and Drug Administration has required that it either go through pre-market clearance as an additive or be examined by experts to establish if it is generally recognized as safe (Salminen et al. 2021). Several investigations have demonstrated postbiotics as bioactive molecules produced by microorganisms' metabolism and released 
into the microbial environment before or after they die. Enzymes, polysaccharides, organic acids, shortchain fatty acids, cell surface proteins, vitamins, and lipids are examples of these essential substances (Aguilar-Toalá et al. 2018).

Gamma-aminobutyric acid (GABA) has potential bio-vital postbiotic functions and is authorized as a dietary supplement with growing evidence of its influence on the gut-brain axis and systemic metabolic health (Mancini et al. 2019). Additionally, it has been shown to exhibit antihypertensive and antidepressive effects on the host after oral treatment (Wu and Shah 2017) preventing epilepsy, depression, diabetic complications, asthma, and cancer, as well, it plays a crucial role in the treatment of neurological disorders (Mele et al. 2019). The glutamic acid decarboxylase (GAD) enzyme, which is greatly increased under certain conditions, enables various lactic acid bacteria to produce abundant levels of GABA, and the food industry sector has capitalized on this ability to develop functional foods rich in GABA (Diez-Gutiérrez et al. 2020). Lactobacillus brevis strains are talented LAB that generates bioactive GABA via the glutamic acid decarboxylase (GAD) enzyme. It also plays a critical part in food processing as GRAS organisms as well as health-promoting probiotics and postbiotics (Wu and Shah 2017, Oleskin and Shenderov 2019, Abdelazez et al. 2022).

Camel milk is a functional superfood that can be used as a substitute for fruits and vegetables in arid and semi-arid regions, supplying the population with essential nutrients from amino and fatty acids that stimulate immunity and prevent the spread of a variety of diseases due to its mineral (magnesium, potassium, iron, copper, zinc, sodium) and it's content of vitamins (C, B2, A, E) (Izadi et al. 2019, Seligsohn et al. 2020). Furthermore, it contains bioactive peptides having therapeutic properties and significant benefits for human health including lactoperoxidase, hydrogen peroxide, lactoferrin, lysozyme, immunoglobulin, and free fatty acid (El-Fakharany et al. 2012). Moreover, its anti-allergic and hypoglycemic benefits, notably among the elderly and diabetics, are attributed to its low cholesterol and sugar content (Khalesi et al. 2017). As a result, camel milk is at the forefront of more effective oral insulin administration strategies since it has higher quantities of the bioactive insulin-like protein as an antidiabetic than other mammals milk (Agrawal et al. 2011, Khan et al. 2013, Kilari et al. 2021). It contains around $52.03 \mu \mathrm{lU} / \mathrm{mL}$ (three times higher than cow milk) depending on the camel species, lactation period (Abdulrahman et al. 2016, Ayoub et al. 2018).

Despite a vast body of evidence demonstrating camel milk's potential to balance glucose, enhance insulin production, reduce insulin resistance, and improve lipid characteristics, as well as strong antidiabetes abilities in clinical trials and both in vitro and in vivo therapies (Shori 2015, Korish et al. 2020). However, the physiological and molecular processes underpinning this evidence are unclear (Ayoub et al. 2018). The study aims to assess the current evidence on the use of camel milk for hyperglycemia and hyperlipidemia therapy, as well as GABA generation and therapeutic characteristics in regulating glucose levels in diabetic $\mathrm{C}_{57} \mathrm{BL} / 6 \mathrm{~J}$ mice as the commercial use in pharmaceutical and nutritional applications.

\section{Materials And Methods}




\section{Growth conditions of bacterial strains}

A single strain of Lactobacillus brevis $\left(\mathrm{KLDS}_{1.0727}\right.$ and $\mathrm{KLDS}_{1.0373}$ ) was acquired from the Key Laboratory of Dairy Science, China. Also included all chemicals and reagents utilized in this study. In De Man Rogosa Sharpe broth (MRS, Oxide), the test strains were inoculated (1\% v/v) and cultured aerobically for $24 \mathrm{~h}$ at $37^{\circ} \mathrm{C}$. Cell pellets were spread onto MRS agar plates and incubated for $24 \mathrm{~h}$ at $37^{\circ} \mathrm{C}$ (Sheldon Manufacturing, Inc., Shel LAB, and Cornelius, OR, USA). A single colony was randomly selected and subcultured three times on fresh MRS agar plates before being transferred to MRS broth and incubated at $37^{\circ} \mathrm{C}$ for $18 \mathrm{~h}$. Finally, cells were cultivated in MRS broth and centrifuged at $8000 \mathrm{rpm}$ for 15 min, (GL-21 M High-Speed Refrigerated Centrifuge, China) to yield cell pellets that were kept in MRS broth enhanced with $30 \%(\mathrm{v} / \mathrm{v})$ glycerol and frozen at $-80^{\circ} \mathrm{C}$ (MDF4V; Panasonic, Tokyo, Japan).

\section{Analyses of bioinformatics and PCR amplification of the 16S rRNA nucleotide sequence}

Lactobacillus brevis $\mathrm{KLDS}_{1.0727}\left(\mathrm{LAC}_{\mathrm{S} 1}\right)$ and $\mathrm{KLDS}_{1.0373}\left(\mathrm{LAC}_{\mathrm{S} 2}\right)$ strains were inoculated $(1 \% \mathrm{v} / \mathrm{v})$ in MRS broth enhanced with $1 \% \mathrm{~L}$-monosodium glutamate (Sigma, USA), and cultured anaerobically at $37^{\circ} \mathrm{C}$ overnight using a glove chamber (Sheldo, USA) provided incubation atmosphere with a gas mixture consisting of $90 \%$ nitrogen, $5 \%$ hydrogen, and $5 \%$ carbon dioxide to help strains to generate postbiotic GABA.

The TIANamp Bacterial DNA Kit (Tiangen Biotech Ltd, Beijing, China) was used to get the Genomic DNA under the manufacturer's extraction guidelines. Furthermore, DNA was extracted once the bacterial cell wall was ruptured with lysozyme. PCR amplification of the 16S rRNA gene fragments was amplified by PCR (GeneAmp PCR System 9700 thermal cycler Applied Biosystem, USA) using primers constructed with the oligo 6 software (Molecular Biology Insights, Inc. DBA Oligo, Inc.) as follows:

gadF:5'CCTCGAGAAGCCGATCGCTTAGTTCG-3'; gadR:5'TCATATTGACCGGTATAAGTGATGCCC-3

The PCR technique stages have previously been described (Abdelazez et al. 2018). $50 \mu \mathrm{L}$ of PCR mixture were divided as ( $1.0 \mu \mathrm{L}$ of DNA template, two primer pairs (ComateBio Custom Primers, Jilin, Changchun, China), gadF/gadR (10 $\mu \mathrm{mol} / \mathrm{L}) ; 2.0 \mu \mathrm{L}$, DNA Polymerase $(2.5 \mathrm{U} / \mu \mathrm{L}) ; 0.5 \mu \mathrm{L}, 10 \times$ Taq Buffer DNA polymerase (Sigma, USA); $5.0 \mu \mathrm{L}, 2^{\prime}$-deoxynucleoside 5' triphosphate (dNTPs), (2.5 mM) $4.0 \mu \mathrm{L}$, and $\mathrm{ddH}_{2} \mathrm{O} 35.5 \mu \mathrm{L}$ ). The PCR techniques were carried out at the denaturation stage ( $95^{\circ} \mathrm{C}$ for $5 \mathrm{~min}$ ). Then came the annealing stage was performed $\left(95^{\circ} \mathrm{C}\right.$ for 30 seconds, $55^{\circ} \mathrm{C}$ for 1.30 minutes). Finally, the elongation stage was performed as $\left(1.30\right.$ minutes at $\left.72^{\circ} \mathrm{C}\right)$. A further extension session of 10 minutes at $72^{\circ} \mathrm{C}$ was added after 30 cycles.

The amplification products were separated by electrophoresis on a $1.5 \%$ agarose gel in TAE buffer $(0.04$ $\mathrm{M}$ Tris-acetate, $1 \mathrm{mM}$ EDTA, pH 8). For one hour, the gel was run at a constant voltage of $100 \mathrm{~V}$ then the gels were stained with $0.2 \mu \mathrm{g} / \mathrm{mL}$ ethidium bromide for $15 \mathrm{~min}$. A UV light transilluminator was used to visualize the PCR products. To determine band sizes, a 100-base pair DNA ladder (Gibco-BRL, Grand 
Island, NY, USA) was loaded into the first lane of each gel. A gel documentation system was used to photograph the gels under UV light (Bio-Rad, Hercules, CA, USA). KLDS ${ }_{1.0727}$ and $\mathrm{KLDS}_{1.0373}$ were compared using sequences taken from the NCBI genome database. (https://www.ncbi.nlm.nih.gov/genome/browse/\#!/prokaryotes/lactobacillus\%20brevis).

\section{Potential probiotic functions of $\mathrm{KLDS}_{1.0727}$ and $\mathrm{KLDS}_{1.0373}$ strains}

Before using Lactobacillus brevis strains in vivo, several in vitro experiments were previously performed to examine their potential ability to survive in harsh GIT conditions such as $(\mathrm{pH}$, bile tolerance, antagonism against pathogens, resistance to several types of antibiotics, viability in simulating gastrointestinal juice, etc.) as free pellets or freeze-dried strains (Abdelazez et al. 2018, Abdelazez et al. 2022).

\section{In vivo experiments}

\section{The experiment protocol}

Under the authorized protocol number specialized pathogen-free rodent management (SRM)-06, the in vivo experiment was carried out in full conformity with the Northeast Agricultural University's institutional animal care and use committee's guidelines, as well as the China Ministry of Science and Technology Guide for the Care and Use of Laboratory Animals as well.

\section{Oral gavage inoculum preparation for a variety of therapies}

For four weeks, $\mathrm{LAC}_{\mathrm{S} 1}$ and $\mathrm{LAC}_{\mathrm{S} 2}$ were subcultured in MRS broth $(1 \% \mathrm{v} / \mathrm{v})$ at $37^{\circ} \mathrm{C}$. Strain pellets were harvested after $18 \mathrm{~h}$, particularly in the third generation, by centrifuging at $2500 \mathrm{rpm}$ for $10 \mathrm{~min}$ at $4^{\circ} \mathrm{C}$. The bacterial pellets were resuspended in sterile PBS after three rinses in phosphate buffer saline (PBS) at a concentration of $5 \times 10^{8} \mathrm{CFU} / \mathrm{mL}$, and the vials inoculum comprised $250 \mu \mathrm{l} /$ mouse. Raw camel milk samples were collected from a bulk tank containing milk from several animals in Taif, Saudi Arabia. The samples were delivered to the animal house lab and stored frozen in a sterile icebox until the study began. One vial of camel milk inoculum containing $100 \mu \mathrm{l} /$ mouse was used in each of the control and diabetic camel therapies.

\section{The experiments' design}

The experiment was designed on seven groups ( $n=4$ mice/group) $\left(\mathrm{C}_{57} \mathrm{BL} / 6 \mathrm{~J}, 16-25 \mathrm{~g} / \mathrm{mice}\right.$, Vital River Laboratory Animal Technology Company, Beijing, China, approval number SCXK, JING, 2012-0001). Mice were adapted for one week in a well-ventilated cage with access to potable water and standard pathogenfree rodent chow in a regular animal house $\left(23 \pm 2^{\circ} \mathrm{C}\right.$, relative humidity $50 \pm 20 \%, 12 \mathrm{~h}$ light/dark). Except for the control group (Cont), which was given $250 \mu$ sterile PBS/day, and camel milk control (Ca Cont $_{\text {) }}$, which was fed $100 \mu \mathrm{l}$ of raw camel milk. The other treated groups were injected with streptozotocin (STZ, 180 
$\mathrm{mg} / \mathrm{kg}$ ) (Sigma, USA) that was newly formulated in $50 \mathrm{mM}$ sodium citrate buffer $(\mathrm{pH} 4.5)$ and delivered subcutaneously within 10 to 15 min after disintegrating for one day (Wu et al. 2011).

Three days after receiving streptozotocin (STZ), animals having glucose concentrations more than 7 $\mathrm{mmol} / \mathrm{dl}$ were deemed diabetic, while mice with low glucose levels were eliminated. There were five groups of diabetic mice in the study. Streptozotocin control (STZ) animals were injected subcutaneously

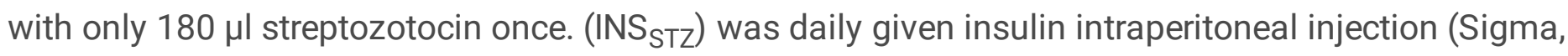
USA) and fed rodent chow for four weeks at a dosage of ( $0.5 \mathrm{unit} / \mathrm{kg}$ body weight). Two groups of strains $\left(\mathrm{LAC}_{\mathrm{S} 1}, \mathrm{LAC}_{\mathrm{S} 2}\right)$ were dissolved in buffered saline and orally gavage at dose intake $250 \mu \mathrm{l} \times 10^{5}$ $\mathrm{CFU} / \mathrm{mL} /$ day, and one group was gavage orally $100 \mu \mathrm{l} /$ day of camel milk (Ca $\left.\mathrm{STZ}_{\mathrm{ST}}\right)$, using a stainless oral needle.

\section{Regular assessments of body weight and hyperglycemia in STZ-induced diabetic mice}

Weekly body weight was conducted using an electronic balance (Hogentogler \& CO. INC. USA). Furthermore, fasting blood glucose after $12 \mathrm{~h}$ and postprandial blood glucose after $2 \mathrm{~h}$ were determined using a glucometer (Contour H Meter, Bayer HealthCare LLC, USA) in blood samples taken from an ophthalmic vein. The postprandial average of glucose levels was calculated using equation (1) (Abdelazez et al. 2018)

Averageofglucoselevels $=$ Postprandial2h - Fasting $12 \mathrm{~h}$

1

\section{Evaluation of hyperlipidemia and glucose levels in blood plasma}

Overnight fasting blood samples were collected from all groups and allowed to coagulate at $4^{\circ} \mathrm{C}$ before being centrifuged at $12.000 \mathrm{rpm} / 10 \mathrm{~min}$ after being humanely sacrificed under diethyl anesthesia. Triglyceride (TG), total cholesterol (CHOL), high-density lipoprotein cholesterol (HDL), and low-density lipoprotein cholesterol (LDL) levels were measured to detect hyperlipidemia. Also, glucose (GLU) was assessed. Notably. all test serum variable parameters were calculated in triplicate using a Beckman Coulter UniCel DxC 800 analyzer (Beckman Coulter, Miami, FL, USA).

\section{Evaluation of liver and renal functions}

To investigate liver functions, serum alanine aminotransferase (ALT), aspartate transaminase (AST), total bile acid (TBA), albumin (ALB), globulin (GLUB), and total protein (TP) levels were assessed. As well, uric nitrogen (BUN), creatinine (CREA), and uric acid (URIC) levels were measured to assess renal function.

\section{Assessment of blood serum insulin}


ELISA kits (Meimian Biotech Co., Ltd., Yan cheng, China) were used to detect serum insulin following the insulin kit manufacturer's guidelines.

\section{Histological analysis}

The liver, pancreas, kidney, and spleen of euthanized mice had been aseptically removed from all test groups (Chen et al. 2012). After being placed in a 10\% formalin solution, the organs were washed in PBS, followed by rinses with graduated alcohol concentrations of $(75,85,95$, and $100 \%)$, as well as xylene $100 \%$. The specimen was then paraffin-fixed and spliced at a thickness of $5 \mathrm{~mm}$ before being stained with hematoxylin and eosin. The slices were inspected at 100 magnifications using light microscopy (Olympus, Japan). Three photos were taken of different organ sections then the average of the affected area/mouse was determined.

\section{Statistical Analysis}

The data are presented as Mean \pm SE. GraphPad Prism was used to create graphs and calculate statistics (versions 8.1 GraphPad). For data analysis, the one-way ANOVA test with $\mathrm{P}<0.05$ as the significant level was utilized to make comparisons between the different groups.

\section{Results}

\section{Evaluation of $\mathrm{GAD}_{65} 16 \mathrm{~S}$ rRNA sequences.}

As part of a prior investigation, 64 strains of lactic acid bacteria were screened in the Key Laboratory of Dairy Science (KLDS) to determine the ideal strains that may carry the glutamic acid decarboxylase 65 $\left(G A D_{65}\right)$ gene and express GABA. The quantity of GABA generated by selected strains was determined using PCR and HPLC. The results of the HPLC quantitative analysis revealed that two (KLDS 1.0727 and $\left.\mathrm{KLDS}_{1.0373}\right)_{\mathrm{LAC}}^{\mathrm{S} 1}, \mathrm{LAC}_{\mathrm{S} 2}$ had the best GABA-producing ability with concentrations of $1.98 \pm 0.07$ and $0.05 \pm 0.05 \mathrm{~g} / \mathrm{L}$, respectively, and a long band of $1.407 \mathrm{bp}$.

\section{Glucose determination during four weeks.}

The results demonstrated that the significant differences $(P<0.05)$ between treatments during the first week were in the INS $\mathrm{STZ}_{\mathrm{S}}$ group, where the glucose concentration was severely reduced, and this trend continued to drop during the third and fourth weeks. Fig. 1 shows the $\operatorname{INS}_{\mathrm{STZ}}(-5.12 \pm 2.12$, and $-7.67 \pm 2.40$ $\mathrm{mmol} / \mathrm{L})$ respectively exhibited the lowest postprandial glucose concentrations when compared to STZ $(6.75 \pm 3.75$ and $6.77 \pm 0.97 \mathrm{mmol} / \mathrm{L})$ in the first and the fourth weeks respectively. However, $\mathrm{Ca}_{\mathrm{Cont}}$ and $\mathrm{Ca}_{\text {STZ }}(1.97 \pm 1.31$ and $1.87 \pm 0.59 \mathrm{mmol} / \mathrm{L})$ respectively exhibited the lowest GLU concentrations in the first week of feeding camel milk when compared to Cont $(3.55 \pm 1.44 \mathrm{mmol} / \mathrm{L})$. Ca ${ }_{\text {Cont }}, \mathrm{Ca}_{\mathrm{STZ}}, \mathrm{LAC}_{\mathrm{S} 1}$, and $\mathrm{LAC}_{\mathrm{S} 2}$ showed $(5.17 \pm 0.18,5.82 \pm 1.07,4.25 \pm 0.83$, and $5.66 \pm 2.84 \mathrm{mmol} / \mathrm{L})$ respectively all had higher in postprandial glucose concentrations than the Cont $(4.15 \pm 0.14 \mathrm{mmol} / \mathrm{L})$ after four weeks of therapy. 


\section{Average of bodyweight throughout four-weeks}

Diabetes type 1 may be identified by measuring both body weight and blood glucose levels. As a result, it is now recognized as a critical metabolic condition characterized by persistent hyperglycemia induced by inadequate insulin secretion. Glycemic control in diabetics is determined by monitoring the proportion of glucose in the blood (Rickels 2020). Significant differences $(P<0.05)$ were seen across groups after the fourth week of treatment. Fig. 2 shows that Cont, $\mathrm{Ca}_{\mathrm{STZ}}$, and INS $\mathrm{STZ}_{\mathrm{STZ}}$ had the highest average body weights $(21.13 \pm 0.68,21.22 \pm 0.50$, and $21.21 \pm 1.07 \mathrm{~g}$, respectively). While STZ showed the lowest average body weight $(18.30 \pm 0.85 \mathrm{~g})$.

Briefly, the effect of STZ inducing diabetes in $\mathrm{C}_{57} \mathrm{BL} / 6 \mathrm{~J}$ mice revealed that the injected with $\mathrm{STZ}$ had a significant impact on the bodyweight of the STZ group, whereas the other treatment groups had no significant effect. The insulin injected had a considerable effect on the animals that were administered insulin regularly but did not affect the body weight. Gavage mice fed with various types of bacterial strains or camel milk had minimal influence on body weight and had a substantial effect on glucose levels when compared to those that received insulin injections.

\section{Hyperlipidemia and glucose levels analysis in blood plasma}

Figure 3 displays hyperlipidemia and glucose of blood plasma, which includes TG, CHOL, HDL, and LDL. In all treatment groups, the results revealed a high significance $(P<0.05)$. The greatest TG content was found in $\mathrm{Ca}_{\text {Cont }}(8.05 \pm 2.32 \mathrm{mmol} / \mathrm{L})$, whereas $\mathrm{LAC}_{\mathrm{S} 1}$ had the lowest TG level $(0.96 \pm 0.27 \mathrm{mmol} / \mathrm{L})$. In addition, the greatest concentration of $\mathrm{CHOL}$ was found in $\mathrm{Ca}_{\text {Cont }}(13.25 \pm 3.82 \mathrm{mmol} / \mathrm{L})$, while, $\mathrm{INS}_{\mathrm{STZ}}$ showed the lowest $\mathrm{CHOL}$ concentration $(3.38 \pm 0.97 \mathrm{mmol} / \mathrm{L})$. Furthermore, Cont had the highest $\mathrm{HDL}$ and LDL values $(4.2 \pm 0.63$, and $1.14 \pm 0.32 \mathrm{mmol} / \mathrm{L})$ respectively, whereas STZ had the lowest HDL $(1.54 \pm 0.44$ $\mathrm{mmol} / \mathrm{L})$. Furthermore, $\mathrm{LAC}_{\mathrm{S} 1}$ had the lowest $\mathrm{LDL}$ concentration $(0.38 \pm 0.10 \mathrm{mmol} / \mathrm{L})$. As a result, all treatments were found to be within the LDL reference range, and all treated groups were determined to be within the HDL range, except for Cont, which had the highest HDL level. Also, there was a significant difference in GLU levels $(P<0.05)$. INS $\mathrm{STZ}_{\mathrm{ST}}$ has the greatest $(9.4 \pm 2.71 \mathrm{mmol} / \mathrm{L})$ and $\mathrm{LAC}_{\mathrm{S} 1}$ has the lowest GLU levels ( $3.1 \pm 0.89 \mathrm{mmol} / \mathrm{L})$.

\section{Determination of insulin blood plasma}

Figure 4 depicts the insulin blood plasma concentrations, which showed no significant difference $(P<0.05) . \mathrm{Ca}_{\mathrm{STZ}}$ and $\mathrm{Ca}_{\text {Cont }}$ had the highest insulin concentrations $(14.14 \pm 0.11$ and $13.52 \pm 0.13 \mu \mathrm{lU} / \mathrm{mL})$ respectively, while INS $\mathrm{STZ}$ had the lowest $(10.27 \pm 0.43 \mu \mathrm{IU} / \mathrm{mL})$. Briefly, all of the observed results fell within the insulin references range.

\section{Assessment of liver functions}

Figure 5 demonstrated that INS $\mathrm{STZ}_{\mathrm{S}}$ had the lowest TP concentrations $(58.1 \pm 16.77 \mathrm{~g} / \mathrm{L})$ compared to STZ, which had the highest TP level $(172.1 \pm 49.68 \mathrm{~g} / \mathrm{L})$. Conversely, the results revealed that all treatments were highest in the reference range except for INS $\mathrm{STZ}$. Also, it was significant differences at $(P<0.05)$. 
$\mathrm{Ca}_{\text {Cont }}$ had the lowest ALB concentration $(33.7 \pm 9.72 \mathrm{~g} / \mathrm{L})$, whereas INS $\mathrm{STZ}_{\mathrm{ST}}$ had the highest ALB level $(58.8 \pm 16.97 \mathrm{~g} / \mathrm{L})$. Except for INS $\mathrm{STZ}_{\mathrm{Z}}$ all treatments were highest in the reference range, as the results demonstrated.

The highest GLUB concentration was found in STZ $(113.3 \pm 32.70 \mathrm{~g} / \mathrm{L})$, whereas the lowest was found in $\mathrm{LAC}_{\mathrm{S} 1}(24.47 .04 \mathrm{~g} / \mathrm{L})$. Cont showed the greatest TBA value $(8.5 \pm 0.63 \mathrm{mmol} / \mathrm{L})$, while the lowest was observed in $L C_{S 1}(2.6 \pm 0.75 \mathrm{mmol} / L)$. On the other hand, STZ showed the highest levels of ALT and AST $(851 \pm 245.66$ and $1785 \pm 515.28 \mathrm{IU} / \mathrm{L})$ respectively. While $L_{A C}{ }_{S 1}$ had the lowest level $(174 \pm 50.56 \mathrm{IU} / \mathrm{L})$. Notably, GLUB revealed that STZ was the highest in the reference range, whereas $L_{A C}{ }_{S 1}$ was the lowest. The TBA reference range was met by all treatments. On the contrary, all therapies massively increased ALT and AST levels over the reference range.

\section{Assessment of renal functions}

The obtained results in Fig. 6 revealed that all treatments were exceeded the BUN reference range. While all therapies had a wider CREA reference range, except for $L C_{S 1}(37.4 \pm 10.79 \mathrm{mmol} / \mathrm{L})$, which had the lowest CREA concentration, and STZ, which had the greatest CREA concentration $(121.5 \pm 35.07 \mathrm{mmol} / \mathrm{L})$. Conversely, all treatments were within the URIC reference range. The obtained URIC results showed that there was no abnormal increase in renal function at $(P<0.05)$. While BUN and CREA showed significantly different at $(P<0.05)$ for all treatments. However, BUN and CREA showed a significant difference at $(P<0.05)$.

\section{Histological evaluation}

Figure 7 depicts a histological examination of (liver; kidney; spleen, and pancreas). Cont shows that the liver has no aberrant shape, cytoplasmic nuclei have clean borders, and there is no congestion, denatured fat, or inflammatory cell infiltration. While the renal glomeruli were normal, with no shrinkage or atrophy, and the renal tubules were also normal, no secretions were found in the cavity, and no inflammatory cell infiltration or fibrosis was observed. The spleen has a normal proportion of red pulp and white marrow cells, normal splenic trabecula structure, and lymphocytes with no hyperemia or fibrosis. Pancreatic cells and vessels, which are typical islet cells, did not shrink and showed no signs of fibrosis or expansion.

$\mathrm{Ca}_{\text {cont }}$ reveals no apparent abnormalities or sporadic liver nuclei pyknosis and no inflammatory cell infiltration. Mild fatty deterioration was seen. Meanwhile, there was some glomerular atrophy and renal tubular fusion in the kidney. The spleen had enhanced phagocytic activity as well as lymphopenia. On the other hand, the pancreas shows no abnormalities. $\mathrm{Ca}_{\mathrm{STZ}}$ indicates no apparent abnormalities or sporadic hepatic nuclei pyknosis and no inflammatory cell infiltration in the liver. Meanwhile, the kidney has atrophy and glomerular shrinkage was visible in the renal tube, which has fused. The spleen displayed enhanced phagocytic and lymphopenia, whereas the pancreas exhibited no abnormalities.

STZ had minor hepatic steatosis, and inflammatory cells aggregated in heaps and spread. While renal glomeruli shrank or atrophy and renal tubules were considered normal, no secretions were found in the 
cavity, and no inflammatory cell infiltration or fibrosis was observed. Meanwhile, the spleen revealed that the number of lymphocytes had decreased and their structure had been destroyed. Pancreatic cells exhibit vacuolar degeneration, and islet atrophy is noticeable. INS $_{\mathrm{STZ}}$ revealed the liver displays a little fatty degeneration and was mildly denatured. With secretions that occur in the cavity, renal glomeruli shrank or atrophy, and renal tubules had epithelial cells fall off. The spleen had an enhanced trabecular and lymphatic reduction, as well as a loss of structure. Pancreatic islet cells revealed severe shrinkage, as well as widespread vacuolar degeneration.

$\mathrm{LAC}_{\mathrm{S} 1}$ showed the hepatic nucleus and exhibited a modest shrinkage of the liver. Pancreatic cells had exhibited no alterations. There were fewer lymphocytes in the spleen tissue, the glomerulus was normal, and the renal tubes were partially fused, but no other abnormalities are seen. $\mathrm{LAC}_{\mathrm{S} 2}$ demonstrates that the liver has normal morphology. The number of trabecular cells in the spleen and the number of phagocytes in the spleen increased. There had been no changes in pancreatic cells. The glomerulus was also normal, and the renal tubes are slightly fused but otherwise normal.

\section{Discussions}

A dysbiosis of the gut microbiota can lead to a variety of disorders, including (type 1 diabetes and cancer). As a result, the gut microbiota must be altered. Postbiotics are substrates that are created or synthesized by microbial metabolic activities and have a direct or indirect beneficial impact on the host (Źółkiewicz et al. 2020, Salminen et al. 2021). GABA synthesis capacity of LAB varies between species and even within species, and it may be connected to glucose metabolism and growth rate (Cataldo et al. 2020).

Several lactic acid bacteria such as Lactobacillus rhamnosus, Lactobacillus reuteri, and Bifidobacterium infantis postbiotic supplementation increased GABA activity and improved oxidative balance (Bagheri et al. 2019). Furthermore, Tian et al. (2004) showed that administering the GABA molecule as a medicinal agent can reduce inflammatory responses and the development of pre-diabetes. Wan et al. (2015) discovered that the GABA molecule has a regulatory effect on human diabetic islands, namely inhibiting insulitis and systemic inflammatory cytokine production.

A blood test reference range is a set of numbers that a health practitioner uses to evaluate a range of medical test results from clinical specimens. Several factors, including age, gender, fitness, and ethnicity, as well as analytical procedures and measuring units, all influence the reference range of the results achieved. Individual results should always be interpreted in light of the test laboratory's testing facility (Virani et al. 2021).

Glucose levels are lower before the first meal and rise for one to two hours after eating. Extra blood glucose levels might indicate the presence of chronic disorders. The findings are consistent with (Rees et al. 2016) who indicated that diabetes was defined as fasting blood glucose levels of more than 7 $\mathrm{mmol} / \mathrm{dL}$ to $11.1 \mathrm{mmol} / \mathrm{dL}$ or higher with hyperglycemia symptoms. Sacks et al. (2011) reported the GLU 
reference range was $3.57-6.12 \mathrm{mmol} / \mathrm{Lb}$. As a result of the rapid shock of insulin injection, all test

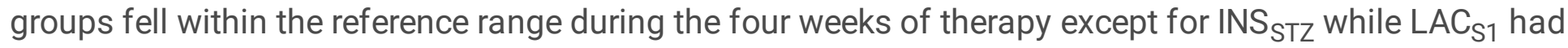
the lowest postponed glucose level after humanely sacrificing the mice.

Insulin is the most important factor in improving plasma glucose homeostasis. The results are consistent with the findings of (Graham et al. 2007) who revealed that the insulin range in blood plasma ranges between 3 and $19 \mathrm{lU} / \mathrm{ml}$.

Kris-Etherton et al. (2021) reported the HDL and LDL reference ranges are $2.07-3.63 \mathrm{mmol} / \mathrm{dL}$. These signs were consistent with the acquired results, which revealed that the $L A C_{S 1}$ and $L A C_{S 2}$ strains had a little similarity in the American Heart Association-recommended ranges (Virani et al. 2021). Also, in diabetic mice, TP, GLUB, and ALB, as well as ALT, AST, and TBA were examined to assess liver functions. (Contreras-Zentella and Hernández-Muñoz 2016), Kris-Etherton et al. (2021) indicated that the reference range for TP was 60.0-80.0 g/Lb, ALB was 35.0-55.0 g/L, and GLUB was 25.0-40.0 g/Lb.

Changes in ALT and AST levels are likely the most commonly employed in clinical diagnosis and research concerning liver damage and tissue activities. According to (Contreras-Zentella and Hernández-Muñoz 2016), a rise or reduction in AST and ALT levels might occur as a result of liver injury, which causes changes in cell membrane permeability. Furthermore, (Saravanakumar et al. 2021) revealed that (ALT, AST), and TBA levels were (1.0 - 40.0 IU/lb) and 0.01-20.0 mmol/Lb, respectively, and discovered that streptozotocin raises AST, ALT, and ALP levels in blood plasma. Furthermore, the findings were consistent with those of (Newsome et al. 2018), who reported that the reference ranges for TP, ALB, and GLUB were $60.0-80.0 \mathrm{~g} / \mathrm{dL}, 35.0-55.0 \mathrm{~g} / \mathrm{dL}$, and $25.0-40.0 \mathrm{~g} / \mathrm{dL}$, respectively.

Renal dysfunction is caused by hyperuricemia, hyperglycemia, and hypertension. Also, diabetics kidney failure is one of the leading causes of mortality. Therefore, one of the most significant indications of renal activity, vitality, and overall health are kidney function tests (Stevens and Levin 2013).

Stevens and Levin (2013), (Ibraheem et al. 2016) displayed the BUN reference range was 1.07-7.14 $\mathrm{mmol} / \mathrm{Lb}$, the CREA reference range was 53.0 - $132.0 \mathrm{mmol} / \mathrm{Lb}$, and the URIC reference range was 142.0 $401.0 \mathrm{mmol} / \mathrm{L}$. The results show that the creatinine levels in the treatment groups were within the safe range of $53.0-132.0 \mathrm{mmol} / \mathrm{Lb}$, which is one of the most important kidney function tests and the results of which are used to evaluate renal functions. Furthermore, serum creatinine measurement is a simple test that may be used to determine the cause of acute renal injury or dehydration, and it is the most common indicator of kidney function (Harloff et al. 2021).

Camel milk has an insulin-like protein that mimics the interaction of insulin with its receptors, is resistant to proteolysis, and has higher storage buffering capacity than other ruminants milk (El-Sayed et al. 2011, Swelum et al. 2021). It is also encapsulated in nanoparticles such as lipid vesicles and rapidly absorbed into the circulation. As a consequence, innovative oral insulin treatment strategies might be investigated (Ashraf et al. 2021). Furthermore, it has a high concentration of zinc, which is essential for the activity of insulin production in pancreatic $\beta$-cells (Deeba et al. 2020). Camel milk's functional purpose is not limited 
to stimulating, increasing, and boosting insulin production; it also aids in the development and improvement of pancreatic $\beta$-cells efficiency (Ayoub et al. 2018).

The results were compared to those of (Dikhanbayeva et al. 2021, Manaer et al. 2021) studies that investigated the effect of camel milk consumption on type 1 diabetes mellitus, regardless of whether the clinical treatment duration was 3 months or 6 months. Patients who consumed camel milk for a short or extended time had substantial drops in blood glucose levels. as well as insulin needs. Furthermore, they investigated insulin sensitivity and glycemic control in individuals with type 1 and type 2 diabetes, discovering that blood glucose levels and insulin requirements reduced dramatically both fasting and postprandial (Mudgil et al. 2018). Furthermore, lower LDL cholesterol levels, hypoglycemia, and an increase in immunostimulants, anticancer, and antimicrobial agents, all of which are supported by camel milk for consumers, are accountable for an improvement in consumer overall health (Esraa 2016).

In diabetic rabbits, frequent camel milk consumption avoided oxidative damage (Aqib et al. 2019), whereas, in diabetic rats, raw camel milk decreases blood glucose levels by $55 \%$, compared to $43 \%$ for raw cow milk (El-Zahar et al. 2021). Furthermore, (Khan et al. 2013) discovered a considerable decline in blood glucose levels of nearly 30\% in STZ-induced rats given camel milk for 6 weeks, from 560 to 235 $\mathrm{mg} / \mathrm{dL}$ compared to rats given buffalo milk or cow's milk.

Camel milk feeding lowers the percentage of lipid peroxide (malondialdehyde levels) and catalase activity while raising glutathione and superoxide dismutase (SOD) levels in STZ-induced diabetic rabbits. Furthermore, camel milk has a significant influence on insulin receptor function and glucose transfer in insulin-sensitive organs such as the liver and pancreas, both of which play key roles in the maintenance of blood glucose homeostasis (Al-Hashem et al. 2009). On the contrary, (Fallah et al. 2020) discovered that the hypoglycemic benefits of camel milk on type 2 diabetes patients can only be sustained when combined with diabetic medicines. Furthermore, (Ejtahed et al. 2015) discovered no change in glucose, lipids, or blood pressure parameters after consuming camel or cow's milk.

\section{Conclusion}

Postbiotics, such as Gamma-aminobutyric acid, were shown to promote human health and to be effective as food additives. Furthermore, camel milk was conventionally regarded as a traditional functional food. As a result, the current study proposes to evaluate the effects of $\mathrm{KLDS}_{1.0727}$ and $\mathrm{KLDS}_{1.0373}$ strains on hyperglycemia and hyperlipidemia in STZ-induced $\mathrm{C}_{57} \mathrm{BL} / 6$ mice. Our findings indicate that GABA and camel milk can regulate blood glucose levels in mice without causing serious injury to the organs and can improve the overall composition of blood plasma. The study's findings suggested that using camel milk to manage type 1 diabetes has extremely promising results due to the high concentration of insulinlike protein. However, further research is needed before camel milk may be used as an alternative source of oral biotherapy for some medications, such as insulin. Furthermore, we recommended a greater emphasis on the creation of dietary items enriched with postbiotics GABA, as well as innovative pharmabiotics applications. 


\section{Declarations}

Author contributions The study's conception and design were contributed to by all authors. Amro Abdelazez and Heba Abdelmotaal performed conceptualization, methodology, writing review, and editing; Amro Abdelazez, Garsa Alshehry, Eman Algarni, Huda Al-jumayi, and Heba Abdelmotaal performed investigation, formal analysis, methodology, and writing-original draught preparation; and Xiang-Chen Meng performed supervision.

Funding: This research was funded by the National Key Research and Development Program of China under Grant no. 2017YED0400304

Conflicts of Interest The authors state that there were no conflicts of interest.

\section{References}

1. Abdelazez A, Abdelmotaal H, Evivie SE, Bikheet M, Sami R, Mohamed H, Meng XC (2022) Verification of Lactobacillus brevis tolerance to simulated gastric juice and the potential effects of postbiotic gamma-aminobutyric acid in streptozotocin-induced diabetic mice. Food Sci. Hum. Wellness 11:165176. https://doi.org/10.1016/j.fshw.2021.07.017.

2. Abdelazez A, Abdelmotaal H, Evivie SE, Melak S, Jia FF, Khoso MH, Zhu ZT, Zhang LJ, Sami R, Meng XC (2018) Screening potential probiotic characteristics of Lactobacillus brevis strains in vitro and intervention effect on type I diabetes in vivo. Biomed. Res. Int 2018:7356173. https://doi.org/10.1155/2018/7356173.

3. Abdulrahman AO, Ismael MA, Al-Hosaini K, Rame C, Al-Senaidy AM, Dupont J, Ayoub MA (2016) Differential effects of camel milk on insulin receptor signaling-toward understanding the insulin-like properties of camel milk. Front. Endocrinol 7:4. https://doi.org/10.3389/fendo.2016.00004.

4. Agrawal R, Jain S, Shah S, Chopra A, Agarwal V (2011) Effect of camel milk on glycemic control and insulin requirement in patients with type 1 diabetes: 2-years randomized controlled trial. Eur. J. Clin. Nutr 65:1048-1052. https://doi.org/10.1038/ejcn.2011.98.

5. Aguilar-Toalá JE, Garcia-Varela R, Garcia Mata-Haro H S, González-Córdova V, et al (2018) Postbiotics: An evolving term within the functional foods field. Trends Food Sci. Technol 75:105-114. https://doi.org/10.1016/j.tifs.2018.03.009.

6. Al-Hashem F, Mohammad D, Bashir N, Mohammad A, Riyadh E, Mohammad K, Al-Khateeb M (2009) Camel's milk protects against cadmium chloride-induced toxicity in white albino rats. Am J. Pharmacol Toxicol 4:107 - 117. https://doi.org/10.3923/jpt.2009.107.116.

7. Aqib Al, Kulyar MFA, Ashfaq K, Bhutta ZA, Shoaib M, Ahmed R (2019) Camel milk insulin: Pathophysiological and molecular repository. Trends Food Sci Technol 88:497 - 504. https://doi.org/10.1016/j.tifs.2019.04.009.

8. Ashraf A, Mudgil P, Palakkott A, Iratni R, Gan CY, Maqsood S, Ayoub MA (2021) Molecular basis of the anti-diabetic properties of camel milk through profiling of its bioactive peptides on dipeptidyl 
peptidase IV (DPP-IV) and insulin receptor activity. J. Dairy Sci 104:61 - 77.

https://doi.org/10.3168/jds.2020-18627.

9. Ayoub MA, Palakkott AR, Ashraf A, Iratni R (2018) The molecular basis of the anti-diabetic properties of camel milk. Diabetes Res. Clin. Pract 146:305 - 312.

https://doi.org/10.1016/j.diabres.2018.11.006.

10. Bagheri S, Heydari A, Alinaghipour A, Salami M (2019) Effect of probiotic supplementation on seizure activity and cognitive performance in PTZ-induced chemical kindling. Epilepsy\&Behavior 95:43-50. https://doi.org/10.1016/j.yebeh.2019.03.038.

11. Cataldo PG, Villegas JM, de Giori GS, Saavedra L, Hebert EM (2020) Enhancement of $Y$-aminobutyric acid (GABA) production by Lactobacillus brevis CRL 2013 based on carbohydrate fermentation. Int. J. Food Microbiol 333:108792. https://doi.org/10.1016/j.ijfoodmicro.2020.108792.

12. Chen L, Magliano DJ, Zimmet PZ (2012) The worldwide epidemiology of type 2 diabetes mellituspresent and future perspectives. Nat. Rev. Endocrinol 8: 228 - 236.

https://doi.org/10.1038/nrendo.2011.183.

13. Contreras-Zentella ML, Hernández-Muñoz R (2016) Is liver enzyme release really associated with cell necrosis induced by oxidant stress?. Oxid. Med. Cell. Longev 2016: 3529149. https://doi.org/10.1155/2016/3529149.

14. Deeba F, Qureshi AS, Kamran M, Farooq A, Faisal N, Muzaffar H, Usman M (2020) Short-term therapeutic efficacy of camel milk Vis-À-Vis buffalo milk in Alloxan ${ }^{\circledR}$ induced diabetic rabbits. J. Diabetes Metab. Disord 19:915 - 923. https://doi.org/10.1007/s40200-020-00580-7.

15. Di Martino G, Di Giovanni P, Cedrone F, Meo F, Scampoli P, Romano F, Staniscia T (2021) Hospitalization for short-term diabetes-related complications: Focus on patients aged over 85 years. Healthcare 9: 460. https://doi.org/10.3390/healthcare9040460.

16. Diez-Gutiérrez L, San Vicente L, Barron LJR, del Carmen Villaran M, Chávarri M (2020) Gammaaminobutyric acid, and probiotics: Multiple health benefits and their future in the global functional food and nutraceuticals market. J. Funct. Foods 64:103669. https://doi.org/10.1016/j.jff.2019.103669.

17. Dikhanbayeva F, Zhaxybayeva E, Dimitrov Z, Baiysbayeva M, Yessirkep G, Bansal N (2021) Studying the effect of the developed technology on the chemical composition of yogurt made from camel milk. East Eur. J. Enterp. Technol. 3:36 - 48. https://doi.org/10.15587/1729-4061.2021.235831.

18. Ejtahed HS, Naslaji AN, Mirmiran P, Yeganeh MZ, Hedayati M, Azizi F, Movahedi AM (2015) Effect of camel milk on blood sugar and lipid profile of patients with type 2 diabetes: a pilot clinical trial. Int. J. Endocrinol. Metab 13:e21160. https://doi.org/10.5812/ijem.21160.

19. El-Fakharany EM, Abedelbaky N, Haroun BM, Sánchez L, Redwan NA, Redwan EM (2012) Antiinfectivity of camel polyclonal antibodies against hepatitis $C$ virus in Huh7.5 hepatoma. Virol. J 9:1 9. https://doi.org/10.1186/1743-422X-9-201.

20. El-Sayed M, Al-Shoeibi Z, El-Ghany A, Atef Z (2011) Effects of camels milk as a vehicle for insulin on glycaemic control and lipid profile in Type 1 diabetics. Am. J. Biochem. Biotechnol 7:179 - 189. 
https://doi.org/10.3844/ajbbsp.2011.179.189.

21. El-Zahar KM, Hassan MFY, Al-Qaba SF (2021) Protective effect of fermented camel milk containing Bifidobacterium longum BB536 on blood lipid profile in hypercholesterolemic rats. J. Nutr. Metab 2021: 1557945. https://doi.org/10.1155/2021/1557945.

22. Esraa T, Sherbini S, El-Sayed GR (2016) Effect of camels milk feeding on oxidative stresses in experimentally induced diabetic rabbits. Mansoura Vet. Med. J 17:1 - 20.

https://doi.org/10.21608/MVMJ.2016.129861.

23. Fallah Z, Ejtahed HS, Mirmiran P, Naslaji AN, Movahedi AM, Azizi F (2020) Effect of camel milk on glycaemic control and lipid profile of patients with type 2 diabetes: Randomized controlled clinical trial. Int. Dairy J 101:104568. https://doi.org/10.1016/j.idairyj.2019.104568.

24. Graham T, Wason C, Blüher M, Kahn B (2007) Shortcomings in methodology complicate measurements of serum retinol-binding protein (RBP4) in insulin-resistant human subjects. Diabetologia 50:814 - 823. https://doi.org/10.1007/s00125-006-0557-0.

25. Harloff M, Prüschenk S, Seifert R, Schlossmann J (2021) Activation of soluble guanylyl cyclase signalling with cinaciguat improves impaired kidney function in diabetic mice. Br. J. Pharmacol 1:1 16. https://doi.org/10.1111/bph.15425.

26. Ibraheem AS, Seleem AA, El-Sayed MF, Hamad BH (2016) Single or combined cadmium and aluminum intoxication of mice liver and kidney with possible effect of zinc. JOBAZ 77:91 - 101. https://doi.org/10.1016/j.jobaz.2016.12.004.

27. Izadi A, Khedmat L, Mujtahids SY(2019) Nutritional and therapeutic perspectives of camel milk and its protein hydrolysates: A review on versatile biofunctional properties. J. Funct. Foods 60:103441.https://doi.org/10.1016/j.jff.2019.103441.

28. Jones CB, Davis CM, Sfanos KS (2020) The potential effects of radiation on the gut-brain axis. Radiat. Res 193:209-222. https://doi.org/10.1667/RR15493.1.

29. Khalesi M, Salami M, Moslehishad M, Winterburn J, Moosavi-Movahedi AA (2017) Biomolecular content of camel milk: A traditional superfood towards future healthcare industry. Trends Food Sci. Technol 62:49 - 58. https://doi.org/10.1016/j.tifs.2017.02.004.

30. Khan A, Alzohairy MA, Mohieldein AH (2013) Antidiabetic effects of camel milk in streptozotocininduced diabetic rats. Am. J. Biochem. Mol. Biol 3:151 - 158.

https://doi.org/10.3923/ajbmb.2013.151.158.

31. Kilari BP, Mudgil P, Azimullah S, Bansal N, Ojha S, Maqsood S (2021) Effect of camel milk protein hydrolysates against hyperglycemia, hyperlipidemia, and associated oxidative stress in streptozotocin (STZ)-induced diabetic rats. J. Dairy Sci 104:1304-1317. https://doi.org/10.3168/jds.2020-19412.

32. Korish AA, Gader AGMA, Alhaider AA (2020) Comparison of the hypoglycemic and antithrombotic (anticoagulant) actions of whole bovine and camel milk in streptozotocin-induced diabetes mellitus in rats. J. Dairy Sci 103: 30 - 41. https://doi.org/10.3168/jds.2019-16606. 
33. Kris-Etherton PM, Petersen KS, Després JP, Braun L, de Ferranti SD, Furie KL, Lear SA, Lobelo F, Morris PB, Sacks FM (2021) Special considerations for healthy lifestyle promotion across the life span in clinical settings: A science advisory from the American Heart Association. Circulation. 144:e515 e532. https://doi.org/10.1161/CIR.000000000000101.

34. Manaer T, Yu L, Nabi XH, Dilidaxi D, Liu L, Sailike J (2021) The beneficial effects of the composite probiotics from camel milk on glucose and lipid metabolism, liver and renal function, and gut microbiota in db/db mice, BMC Complement. Med. Ther 21:1 - 13. https://doi.org/10.1186/s12906021-03303-4.

35. Mancini A, Carafa I, Franciosi E, Nardin T, Bottari B, Larcher R, Tuohy KM (2019) In vitro probiotic characterization of high GABA producing strain Lactobacillus brevis DSM 32386 isolated from traditional "wild" Alpine cheese. Ann. Microbiol 69:1435-1443. https://doi.org/10.1007/s13213-01901527-x.

36. Mele M, Costa RO, Duarte CB (2019) Alterations in GABAA-receptor trafficking and synaptic dysfunction in brain disorders, Front. Cell Neurosci. 13:77. https://doi.org/10.3389/fncel.2019.00077.

37. Mudgil P, Kamal H, Yuen GC, Maqsood S (2018) Characterization and identification of novel antidiabetic and anti-obesity peptides from camel milk protein hydrolysates. Food Chem 259:46 - 54. https://doi.org/10.1016/j.foodchem.2018.03.082.

38. Newsome PN, Cramb R, Davison SM, Dillon JF, Foulerton M, Godfrey EM, Hall R, Harrower U, Hudson M, Langford A (2018) Guidelines on the management of abnormal liver blood tests. Gut 67:6 - 19. http://dx.doi.org/10.1136/gutjnl-2017-314924.

39. Oleskin AV, Shenderov BA (2019) Probiotics, and psychobiotics: the role of microbial neurochemicals. Probiotics and Antimicro. Prot 11:1071-1085. https://doi.org/10.1007/s12602-019-09583-0.

40. Patil P, Mandal S, Tomar SK, Anand S (2015) Food protein-derived bioactive peptides in management of type 2 diabetes. Eur. J. Nutr 54: 863-880. https://doi.org/10.1007/s00394-015-0974-2.

41. Rees G, Xie J, Fenwick EK, Sturrock BA, Finger R, Rogers SL, Lim L, Lamoureux EL (2016) Association between diabetes-related eye complications and symptoms of anxiety and depression. JAMA Ophthalmol 134:1007 - 1014. https://doi.org/10.1001/jamaophthalmol.2016.2213.

42. Rickels MR (2020) Metabolic and endocrine evaluation of islet transplant function. In Transplantation, bioengineering, and regeneration of the endocrine pancreas, Elsevier pp 565 - 578.

43. Sacks DB, Arnold M, Bakris GL, Bruns DE, Horvath AR, Kirkman MS, Lernmark A, Metzger BE, Nathan DM (2011) Guidelines and recommendations for laboratory analysis in the diagnosis and management of diabetes mellitus. Clin. Chem 57:436 - 472. https://doi.org/10.1093/clinchem/48.3.436.

44. Salminen S, Collado MC, Endo A, Hill C, Lebeer S, Quigley EM, Sanders ME, Shamir R, Swann JR, Szajewska H (2021) The international scientific association of probiotics and prebiotics (ISAPP) consensus statement on the definition and scope of postbiotics. Nat. Rev. Gastroenterol. Hepatol 18:649-667. https://doi.org/10.1038/s41575-021-00522-5. 
45. Saravanakumar K, Park S, Mariadoss AVA, Sathiyaseelan A, Veeraraghavan VP, Kim S, Wang MH (2021) Chemical composition, antioxidant, and anti-diabetic activities of ethyl acetate fraction of Stachys riederi var. Japonica (miq.) in streptozotocin-induced type 2 diabetic mice. Food Chem. Toxicol 155:112374. https://doi.org/10.1016/j.fct.2021.112374.

46. Seligsohn D, Nyman AK, Younan M, Sake W, Persson Y, Bornstein S, Maichomo M, de Verdier K, Morrell J, Chenais E (2020) Subclinical mastitis in pastoralist dairy camel herds in Isiolo, Kenya: Prevalence, risk factors, and antimicrobial susceptibility. J.Dairy Sci 103:4717- 4731. https://doi.org/10.3168/jds.2019-17701.

47. Shori $A B$ (2015) Camel milk as a potential therapy for controlling diabetes and its complications: $A$ review of in vivo studies. J. Food Drug Anal 23609:618. https://doi.org/10.1016/j.jfda.2015.02.007.

48. Stevens PE, Levin A (2013) Evaluation and management of chronic kidney disease: synopsis of the kidney disease: Improving global outcomes 2012 clinical practice guideline. Ann. Intern. Med 158: 825 - 830. https://doi.org/10.7326/0003-4819-158-11-201306040-00007.

49. Suzzi G, Corsetti A (2020) Food microbiology: The past and the new challenges for the next 10 years. Front. Microbiol 11:237. https://doi.org/10.3389/fmicb.2020.00237.

50. Swelum AA, El-Saadony MT, Abdo M, Ombarak RA, Hussein EO, Suliman G, Alhimaidi AR, Ammari AA, Ba-Awadh H, Taha AE (2021) Nutritional, antimicrobial and medicinal properties of camel's milk: A review. Saudi J. Biol. Sci 28:3126 - 3136. https://doi.org/10.1016/j.sjbs.2021.02.057.

51. Tian J, Lu Y, Zhang H, Chau CH, Dang HN, Kaufman DL (2004) Y-Aminobutyric acid inhibits T cell autoimmunity and the development of inflammatory responses in a mouse type 1 diabetes model. $\mathrm{J}$. Immunol 173:5298 - 5304. https://doi.org/10.4049/jimmunol.173.8.5298.

52. Verhaegen A, Van Gaal LF (2021) Drugs affecting body weight, body fat distribution, and metabolic function-mechanisms and possible therapeutic or preventive measures: an update. Curr. Obes. Rep 10: 1-13. https://doi.org/10.1007/s13679-020-00419-5.

53. Virani SS, Alonso A, Aparicio HJ, Benjamin EJ, Bittencourt MS, Callaway CW, Carson AP, Chamberlain AM, Cheng S, Delling FN (2021) Heart disease, and stroke statistics-2021 update: a report from the American Heart Association, Circulation. 143: e254 - e743. https://doi.org/10.1161/CIR.0000000000000950.

54. Wan Y, Wang Q, Prud'homme GJ (2015) GABAergic system in the endocrine pancreas: a new target for diabetes treatment. Diabetes Metab. Syndr. Obes: targets and therapy 8: 79 - 87. https://doi.org/10.2147/DMSO.S50642.

55. Wu CH, Huang SM, Lin JA, Yen GC (2011) Inhibition of advanced glycation endproduct formation by foodstuffs. Food Funct 2: 224 - 234. https://doi.org/10.1039/C1F010026B.

56. Wu Q, Shah NP (2017) High y-aminobutyric acid production from lactic acid bacteria: emphasis on Lactobacillus brevis as a functional dairy starter. Crit. Rev. Food. Sci. Nutr 57:3661-3672. https://doi.org/10.1080/10408398.2016.1147418.

57. Żółkiewicz J, Marzec A, Ruszczyński M, Feleszko W (2020) Postbiotics-a step beyond pre and probiotics. Nutrients 12: 2189.https://doi.org/10.3390/nu12082189. 
Figures

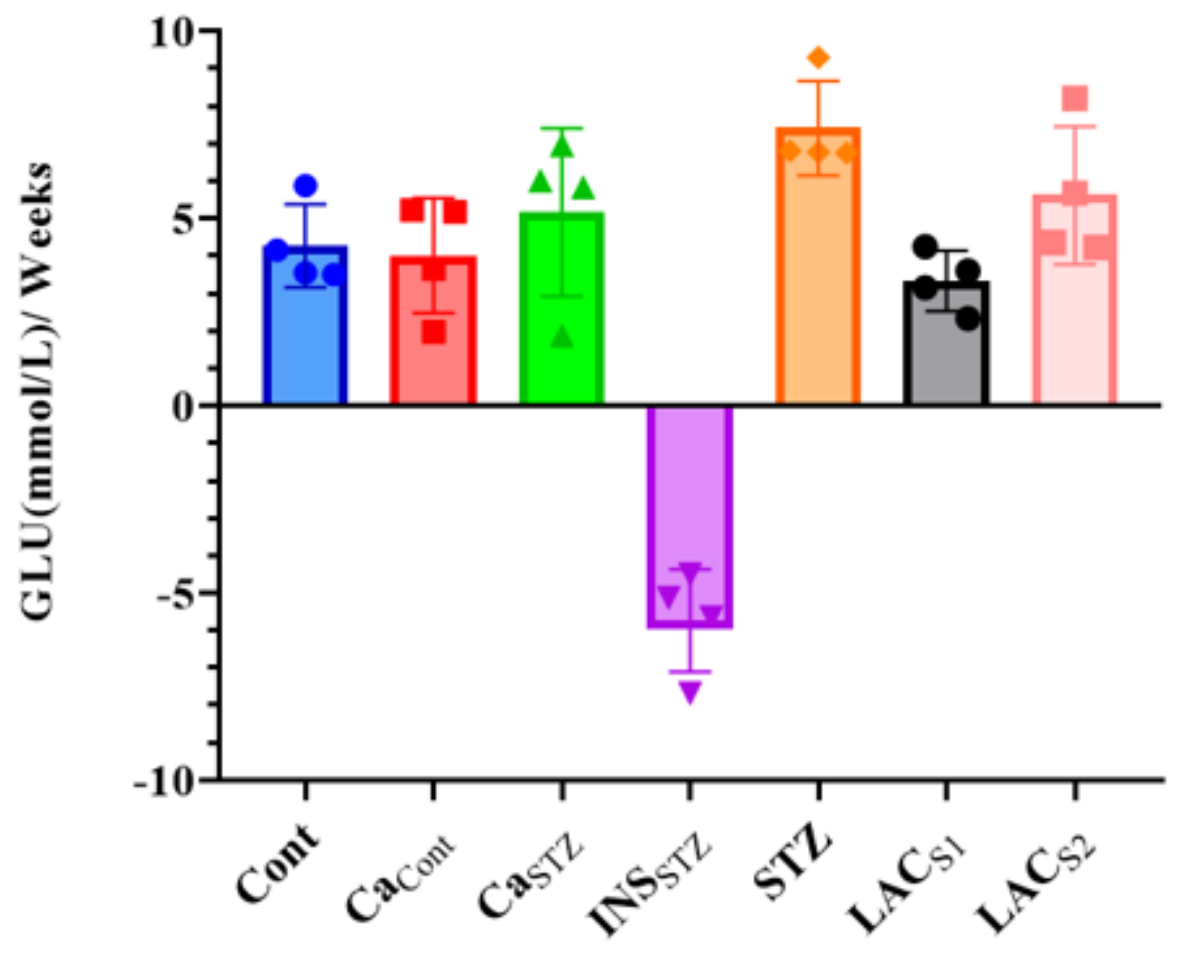

Figure 1

Glucose levels (mmol/L) during four weeks. GLU, Glucose levels ( $\mathrm{mmol} / \mathrm{L})$ during four weeks. Cont, Control; $\mathrm{Ca}_{\mathrm{Cont}}$, Camel milk control; $\mathrm{Ca}_{\mathrm{STZ}}$, Camel milk with streptozotocin; $\mathrm{INS}_{\mathrm{STZ}}$, insulin with streptozotocin; STZ, streptozotocin; $\mathrm{LAC}_{\mathrm{S} 1}, \mathrm{KLDS}_{1.0727}$ and $\mathrm{LAC}_{\mathrm{S} 2}, \mathrm{KLDS}_{1.0373}$ 


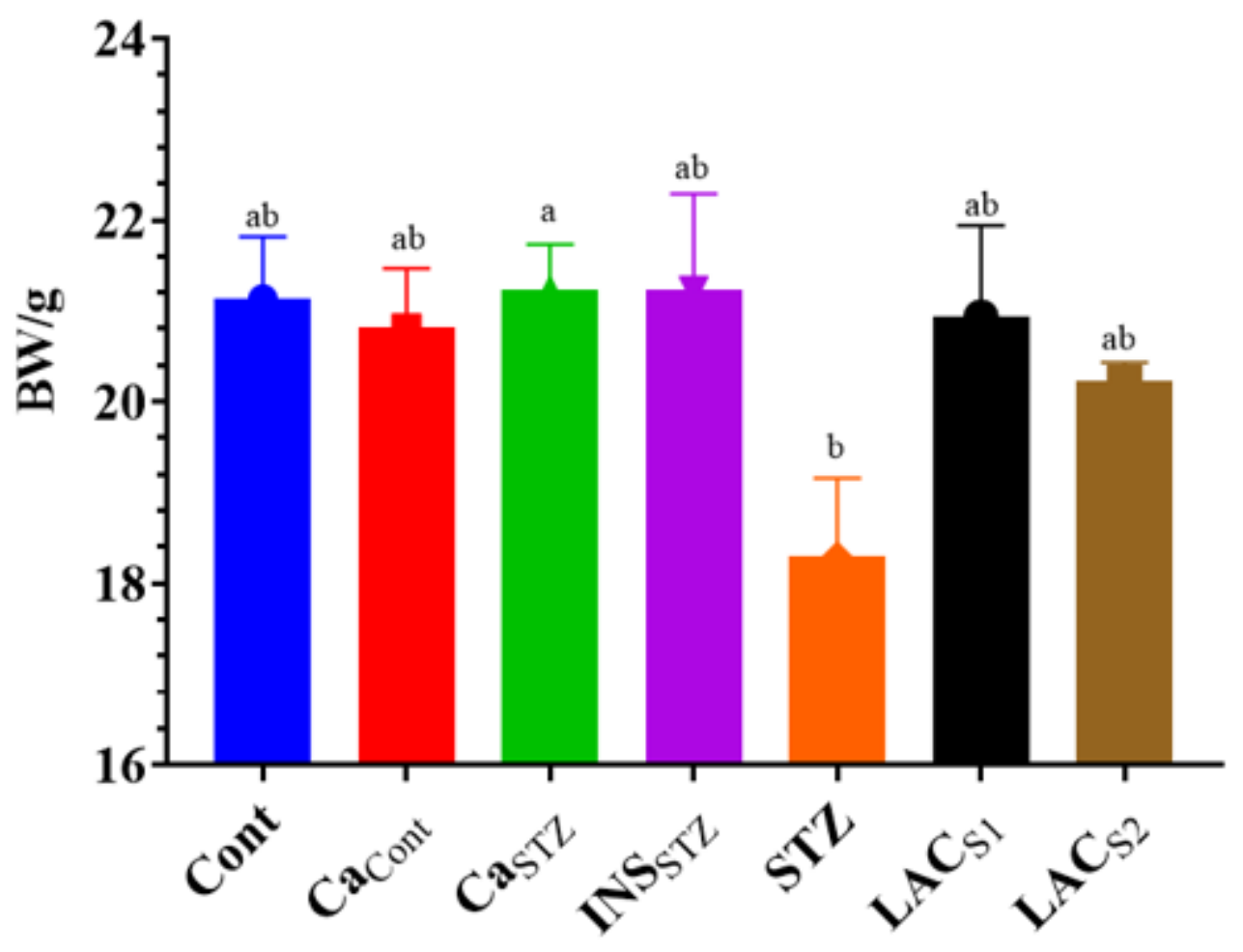

Figure 2

Average of Bodyweight /g during four weeks. BW/g, Average of body weight/g during four weeks. See the footer of Figure 1, Means with the same letter are not significantly different $p<0.05$. 


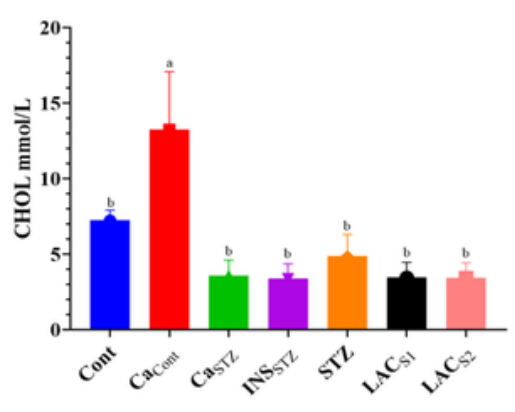

(a) CHOL $(\mathrm{mmol} / \mathrm{L})$

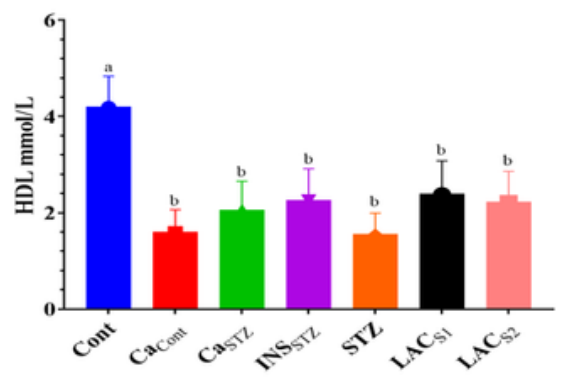

(c) $\mathrm{HDL}(\mathrm{mmol} / \mathrm{L})$

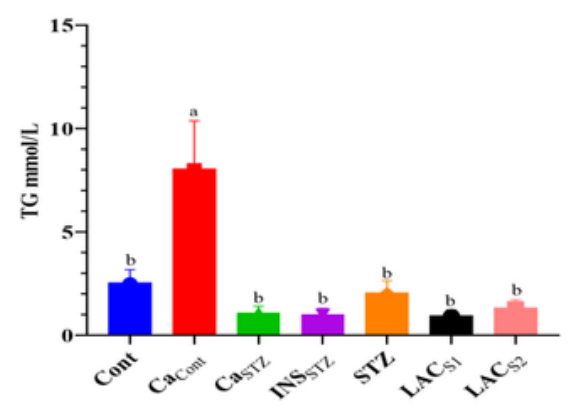

(b) $\mathrm{TG}(\mathrm{mmol} / \mathrm{L})$

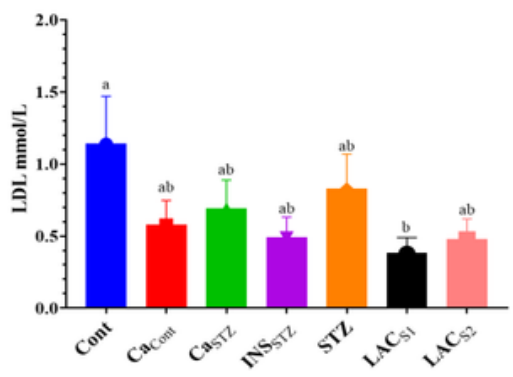

(d) $\mathrm{LDL}(\mathrm{mmol} / \mathrm{L})$

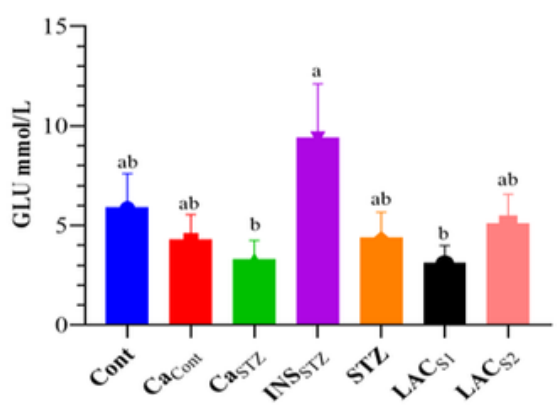

(e) GLU

\section{Figure 3}

Hyperlipidemia and glucose levels analysis in blood plasma Triglycerides (TG), Total cholesterol (CHOL), High-density lipoprotein cholesterol (HDL), Low-density lipoprotein cholesterol (LDL) and Glucose (GLU). See the footer of Figure 1, Means with the same letter are not significantly different $p<0.05$. 


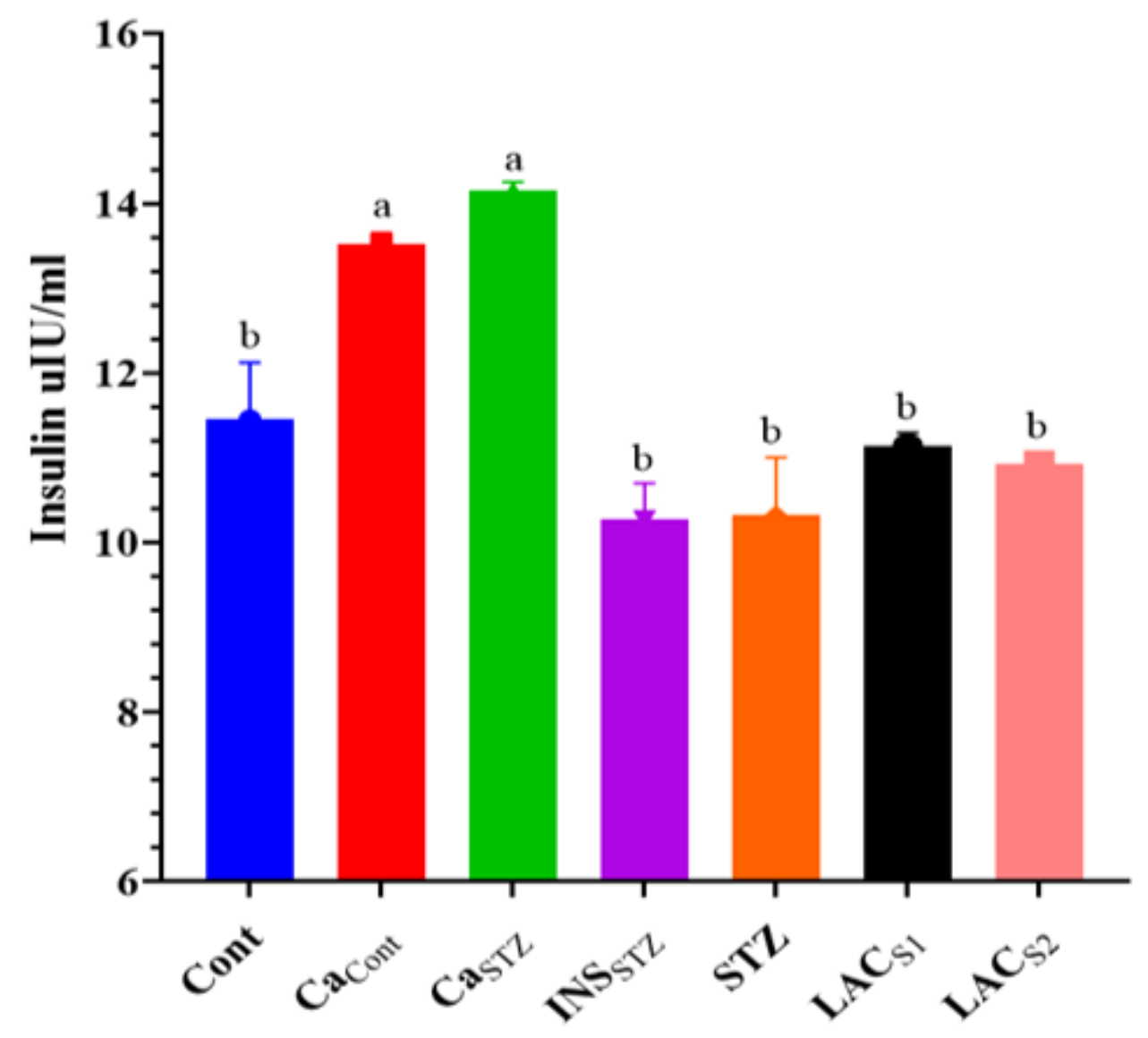

Figure 4

Determination of insulin blood plasma. Insulin of blood plasma

See the footer of Figure 1, Means with the same letter are not significantly different $p<0.05$. 


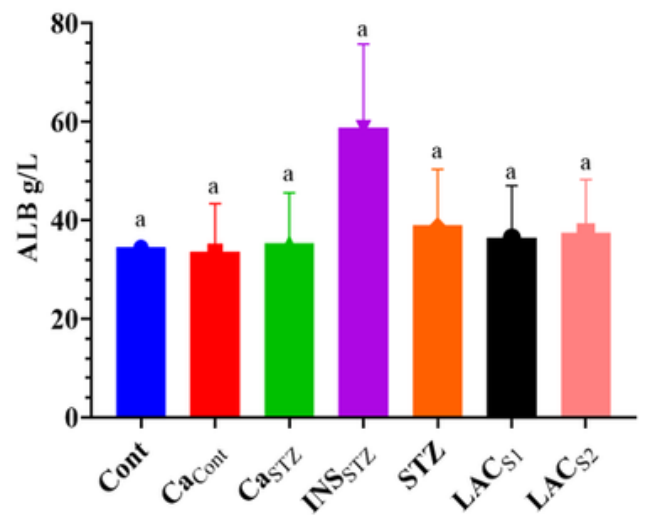

(a) $\mathrm{ALB} g / \mathrm{L}$

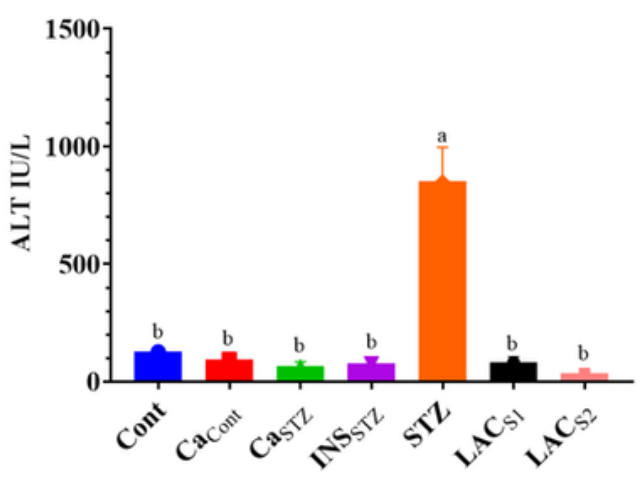

(c) ALT IU/L

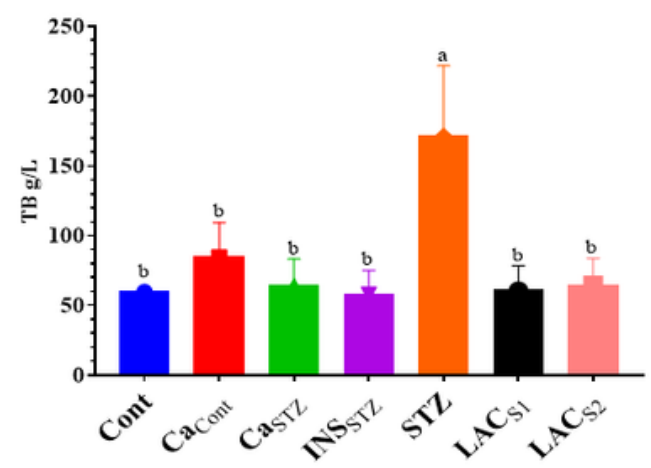

(e) $\mathrm{TB} g / \mathrm{L}$

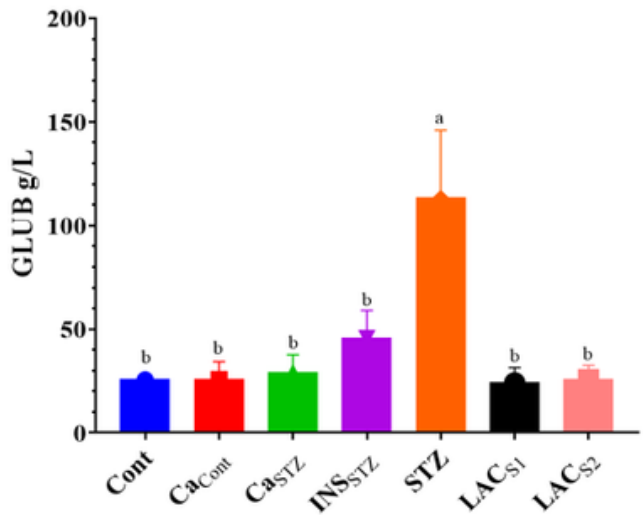

(b) GLUB g/L

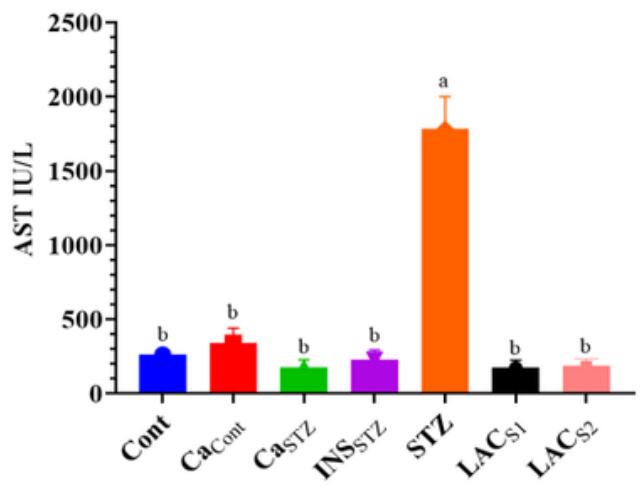

(d) AST IU/L

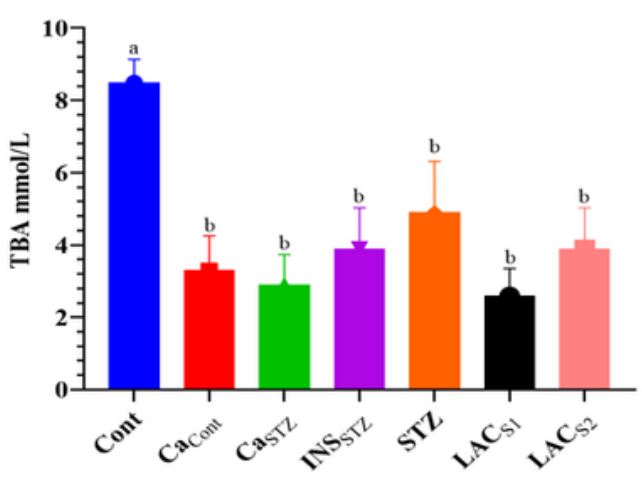

(f) TBA $\mathrm{mmol} / \mathrm{L}$

\section{Figure 5}

Assessment of liver functions. Serum alanine aminotransferase (ALT), Aspartate transaminase (AST), Total bile acid (TBA), Albumin (ALB), Globulin (GLUB), and Total protein (TP). See the footer of Figure 1, Means with the same letter are not significantly different $p<0.05$. 


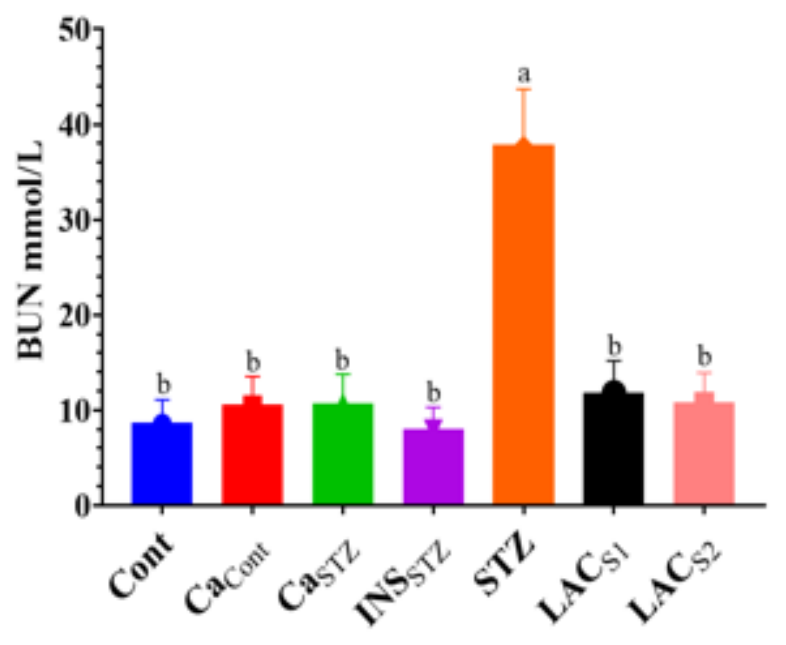

(a) BUN $\mathrm{mmol} / \mathrm{L}$

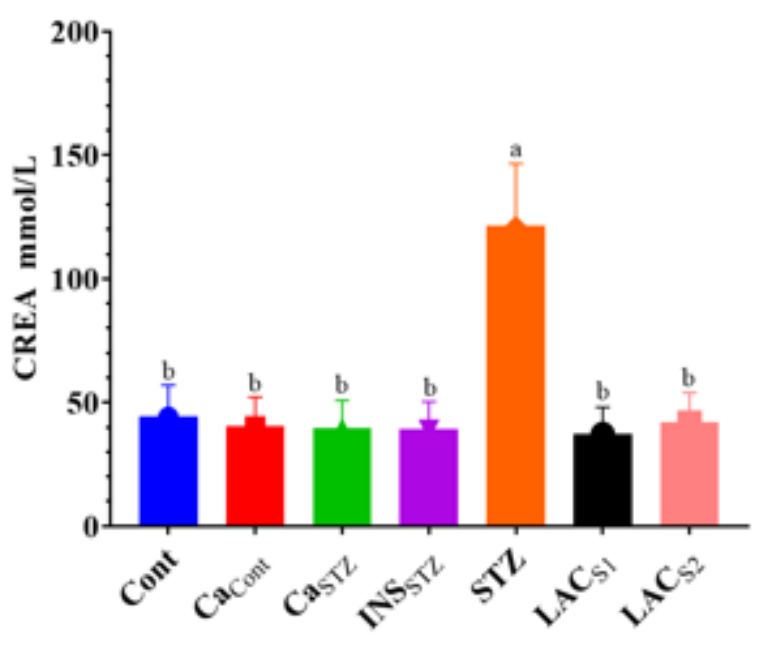

(b) CREA mmol/L

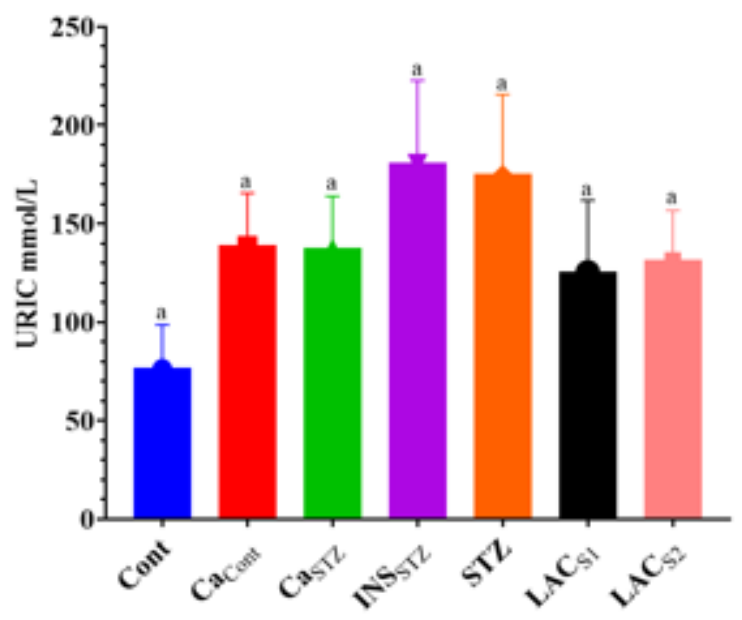

(c) URIC $\mathrm{mmol} / \mathrm{L}$

\section{Figure 6}

Assessment of renal functions. Uric nitrogen (BUN), Creatinine (CREA), and Uric acid (URIC). See the footer of Figure 1, Means with the same letter are not significantly different $p<0.05$. 

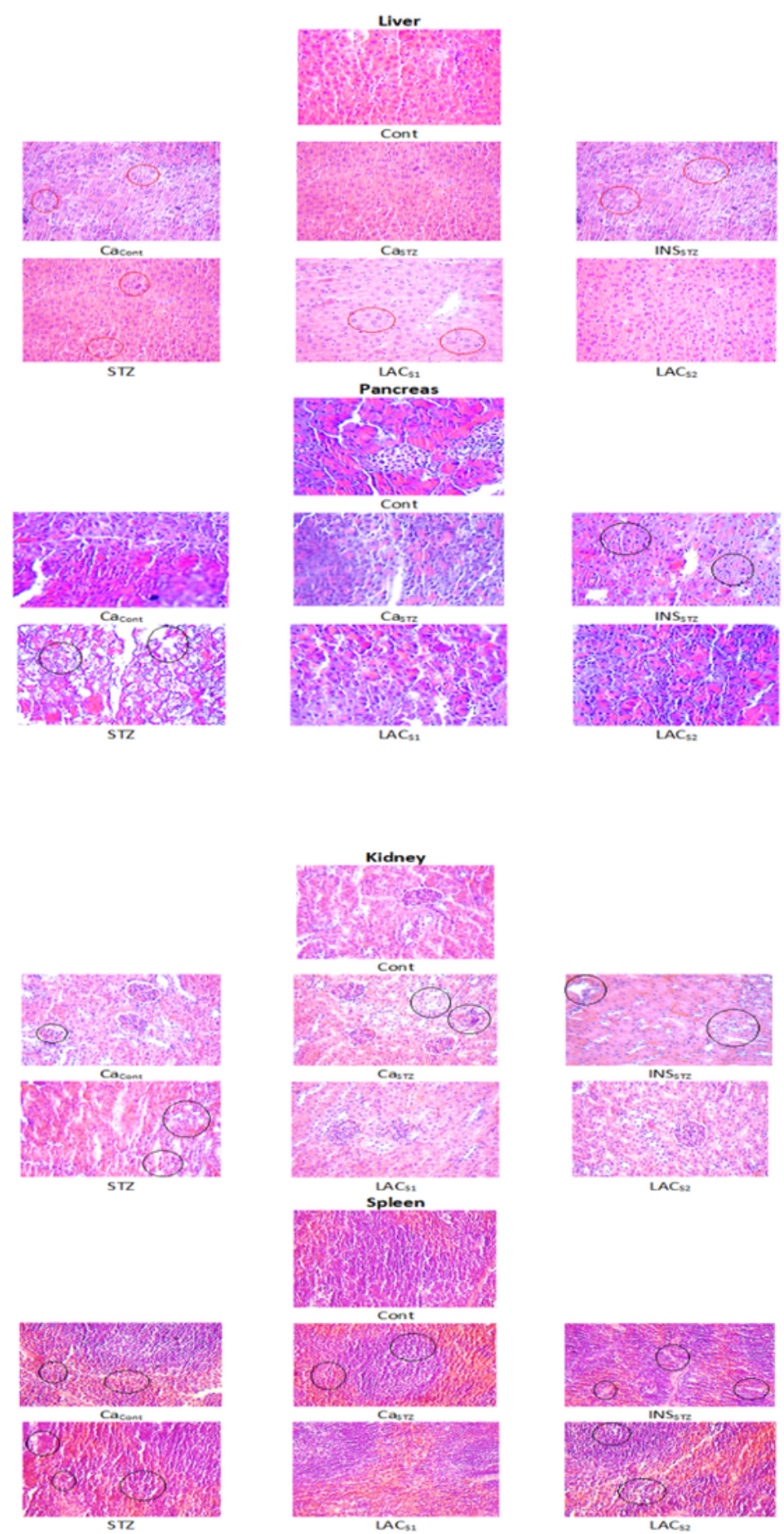

\section{Figure 7}

Histological evaluation See the footer of Figure 1

\section{Supplementary Files}

This is a list of supplementary files associated with this preprint. Click to download. 
- 152912911274Authorchecklist.docx

Page 25/25 